Ann. Biol. anim. Bioch. Biophys., 1978, 18 (2 B), 623-632.

\title{
The movement of fluid in the seminiferous tubules and rete testis
}

\author{
by B. P. SETCHELL, R. V. DAVIES, R. T. GLADWELL, B. T. HINTON, S. J. MAIN,
} Lynn PILSWORTH, G. M. H. WAITES

\author{
Deportment of Biochemistry, A.R. C. Institute of Animal Physiology, \\ Babraham, Cambridge CB2 4AT, U.K. \\ Deportment of Physiology and Biochemistry, \\ University of Reading, Reading, RG6 2AJ, U. K.
}

Summary. The composition of fluid from the seminiferous tubules and rete testis of the rat has been studied. Differences in ionic, steroid and protein concentrations in the two fluids suggest that two different fluids are secreted, but from the numbers of sperm and the concentrations of inositol, it now seems more likely that all the fluid is secreted in the seminiferous tubules but that its composition is modified as it passes through the tubuli recti or when it reaches the rete testis. The permeability of the rete to potassium is appreciably higher than that to sodium ; the latter is comparable to the permeability of the fubules to both ions. The potential difference from blood is similar at the two sites (approx. $5 \mathrm{mV}$ lumen negative).

Movements of fluid along the tubules have been observed using small oil droplets. Fluid moves in either direction and at widely varying rates from time to time. The observed rate of fluid flow supports the suggestion that most of the fluid is formed in the tubules.

Focal lesions produced in one seminiferous tubule « progress» along the fubule and blockage of the lumen also causes a progressive degeneration. From studies on rats with depleted numbers of germ celis, it appears that secretion by the Sertolicells can continue in the absence of germ cells, but that the composition of the secretion may be affected.

The tubular luminal fluid is thus an important possible vehicle for interactions between germ cells and somatic cells inside the tubules.

\section{Infroduction.}

Histological studies suggested that the lumina of the seminiferous tubules and rete testis were filled with aqueous fluid, and this suggestion has been confirmed by direct collection of fluid from both these sites (Setchell and Waites, 1975). It is highly probable that fluid is secreted by non-germinal cells inside the tubules and therefore it provides a potential route for interaction between the somatic and germinal cells. The fluid in the seminiferous tubules may represent a special micro-environment favourable for meiosis, and indeed, meiosis is completed only after fluid secretion has been established (Setchell, 1970). The unusual composition of the fluid in the excurrent duct system is maintained by the blood-testis barrier, which restricts the passage of 
many, but not all substances, between blood plasma and the fluids in the tubules and rete testis (Setchell and Waites, 1975).

However, the significance of the fubular fluid in interactions between somatic cells and germ cells can only be determined when its origin and movements are known. This has been the purpose of the present study.

\section{Materials and methods.}

Collection of testicular fluids. - Rete testis fluid (RTF) can be collected by chronic cannulation in rams, bulls and boars and acutely from rats, monkeys, hamsters and rabbits (Waites, 1977). Seminiferous tubular fluid (STF) can be collected directly by micropunciure in rats and hamsters (Tuck ef al., 1970 ; Levine and Marsh, 1971 ; Howards, Johnson and Jessee, 1975 ; Johnson and Howards, 1977) or its composition calculated from the differences between one testis with its efferent ducts ligated (EDL) 16 to $24 \mathrm{hr}$ before and the contralateral unligated testis (Setchell ef al., 1976). This "difference » technique gives results for ions and inositol which agree well with direct measurements (figs 1 and 2). A « primary » secretion can be demonstrated if a

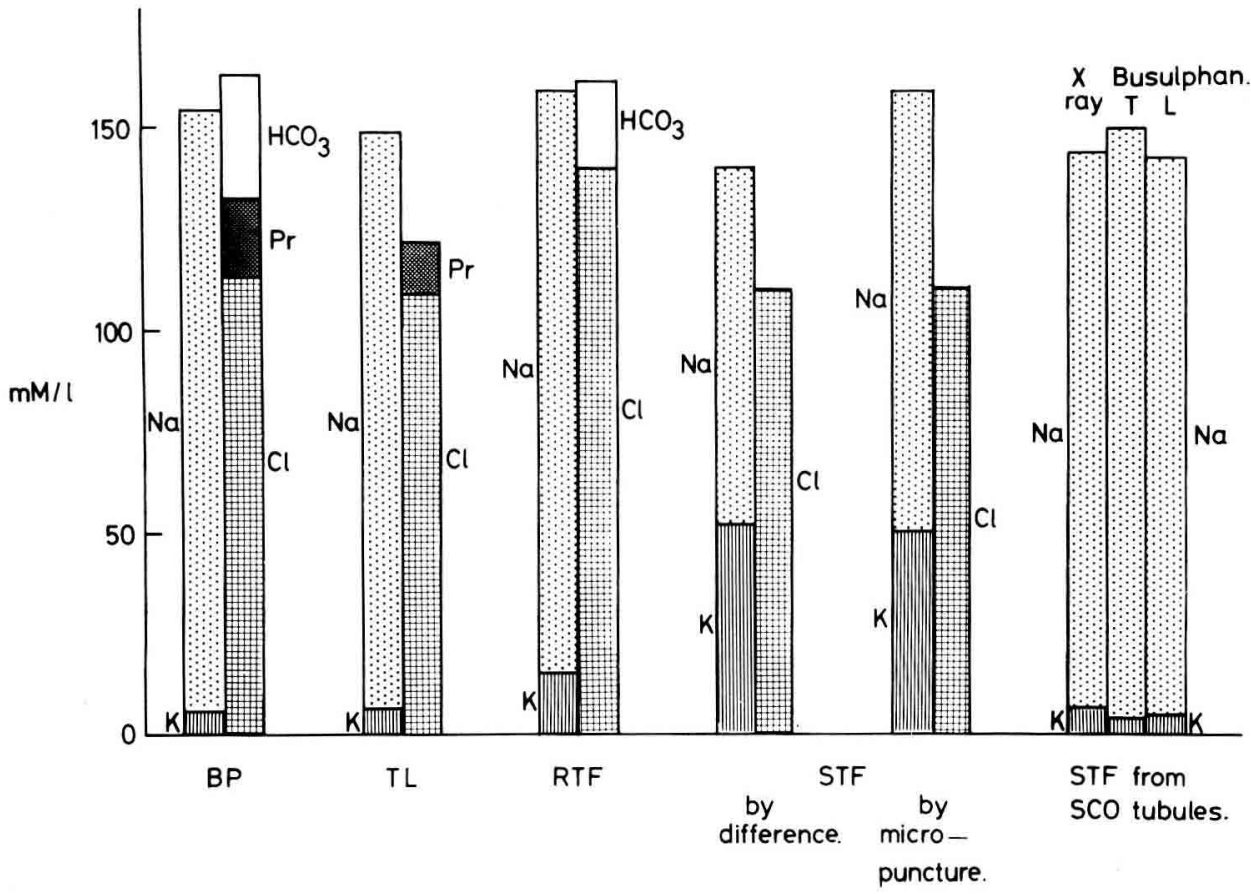

FIG. 1. - The ionic composition of blood plasma (BP), testicular lymph (TL), rete testis fluid (RTF) and seminiferous fubule fluid (STF) obtained by the « difference » technique or by micropuncfure from normal adult rats, or by micropuncture from the fubules of adult rats containing only Sertoli cells (SCO) following treatment in utero with $X$-rays (data of Hinton and Setchell, unpublished observations) or Busulphan (T, data of Tuck, 1969 ; L, data of Levine and Marsh, 1975). 
section of fubule is filled with oil ; continuing secretion by the cells lining the wall of the tubule breaks up the oil with aqueous fluid, which can be removed for analysis (Tuck ef al., 1970).

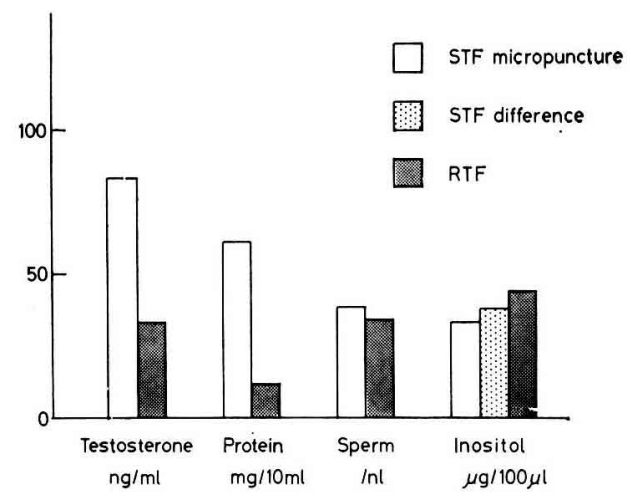

FIG. 2. - The concentrations of testosterone (data of Comhaire and Vermeulen, 1976), protein, spermatoxoa and inositol in rete testis fluid (RTF) and seminiferous fubule fluid (STF) of adult rats.

Analytical techniques. - Sodium and potassium were measured by flame photometry, inositol by a microbiological assay (Hinton, Setchell and White, 1977), and total protein by a modification of the Lowry method (Hartree, 1972) scaled down to detect as little as $0.5 \mu \mathrm{g}$ protein. Spermatozoa were counted in a haemocytometer after appropriate dilution of the samples.

Potential differences. - The potential between the rete testis and blood was measured with a silver-silver chloride electrode inserted through a catheter placed in the rete by technique of Tuck et al. (1970).

Permeability of the wall of the rete and fubules. - Radioactive $\mathrm{Na}^{24}$ and $\mathrm{K}^{42}$ were injected intraperitoneally into rats about $16 \mathrm{hrs}$ after unilateral EDL ; RTF and blood plasma were collected between 1 and $6 \mathrm{hrs}$ after injection of the isotope, and the testes were then removed immediately for the calculations of the concentration of the isotope in the tubular fluid by the « difference » technique.

Fluid movements inside the seminiferous tubules. - Movements of fluid within the tubules were observed by micro-injection of small droplets of paraffin oil stained with Sudan black, by infusing an aqueous solution of Lissamine green through a micropipette with a $10 \mu \mathrm{l}$ microsyringe driven by a Harvard syringe pump, or by injecting an alcoholic solution of Sudan black, which produced a suspension of insoluble dye particles when the alcohol mixed with the aqueous fluid in the tubular lumen.

Lesions and blockages in individual seminiferous tubules. - Lesions were produced by the microinjection of formalin or cadmium chloride solutions (approx. $50 \mathrm{nl}$ of $10 \mathrm{p} .100$ formalin in saline or $20 \mathrm{mg} / \mathrm{ml} \mathrm{CdCl}_{2}$ ). Individual tubules were blocked by injecting enough latex solution (approx. $5 \mathrm{nl}$ of Latex-White-MR - Ballman, Ivy and Carter Ltd - stained with Monastral fast blue) to fill about $1 \mathrm{~mm}$ of tubule. The latex hardens when exposed to aqueous fluids, thereby blocking the tubule. At appropriate 
times afterwards, the rats were anaesthetized and the testis fixed by injections of Bouin's fluid into the testicular artery. Paraffin-embedded sections were cut and stained for histological examination.

Animals. - Wistar strain rats between 250 and $400 \mathrm{~g}$ body weight were used. Sertoli-cell only animals were produced by X-irradiating their mothers (130 Rads, whole body) on the 19th day of pregnancy (Beaumont, 1960). These animals grew more slowly than normal rats and were used when they weighed about $400 \mathrm{~g}$, at about 6 months of age.

\section{Results and discussion.}

\section{Differences between seminiferous tubule fluid (STF) and rete testis fluid (RTF).}

Seminiferous tubule and rete testis fluids are quite different from blood plasma, but they are also different from one another (fig. 1). Primary fluid is even higher in potassium than STF (Tuck et al., 1970) while in rats which, when fetuses, had been treated with Busulphan (Tuck, 1969 ; Levine and Marsh, 1975) or X-irradiated (fig. 1), the fluid in the sperm-free tubules was plasma-like in ionic composition and no secretion of primary fluid could be demonstrated. Tubular fluid is appreciably hyperosmotic, whereas rete fluid is isotonic with plasma (Johnson and Howards, 1977). STF also contains more testosterone than RTF (Combaire and Vermeulen, 1976), and the concentration of total protein is about five times higher in STF than RTF (fig. 2). (Kormano, Koskimies and Hunter (1971) had shown that the protein pattern for the two fluids was different, but had not made any estimates of total protein concentration in STF).

It was originally proposed that primary fluid represented the secretion formed in the tubules and that the fluid normally present there (free-flow fluid) was a mixture of primary fluid and rete secretion, which was drawn back with the tubules. As each tubule is usually two-ended with both ends opening into the rete, such mixing is conceivable, but is difficult to reconcile with the valve-like anatomy of the tubuli recti (Dym, 1974). Furthermore, the two-fluid theory was not supported by later evidence obtained by microperfusion of tubules with solutions of different composition (Henning and Young, 1971). For the present, we envisage secretion in the tubules of a fluid like free-flow fluid which is diluted by the secondary secretions from the rete when it arrives there, and think that some artifact contributed to the high potassium concentration in primary fluid. As chloride is higher in RTF than in either primary fluid, STF or plasma, a simple explanation cannot be given for its behaviour. However, it is not possible to exclude changes in $\mathrm{pH}$ between fubule and rete with consequent changes in the concentration of free $\mathrm{CO}_{2}$, which is much more permeable than bicarbonate ion.

\section{Similarities between STF and RTF.}

It was also suggested that measurements of spermatocrit in STF and RTF supported the two-fluid theory (Tuck ef al., 1970 ; Levine and Marsh, 1971 ; Howards, Johnson and Jessee, 1975). However, it now appears that these measurements may have been 
affected by artifacts due to the different diameters of the tubes used for centrifuging the two types of fluid. When the spermatozoa are counted in measured volumes of the two fluids, the concentrations are almost identical (fig. 2) and spermatocrits determined in tubes of comparable diameters give similar results. The inositol concentration in STF, measured directly or by the " difference " technique, is very similar to that in RTF (fig. 2, Hinton, Setchell and White, 1977). These latter results could be due to synthesis of inositol at an extremely high rate in the rete epithelium, but this seems unlikely, while it is impossible to reconcile the sperm concentrations with the two-fluid theory.

\section{Potentials.}

A potential of about $5 \mathrm{mV}$ (lumen negative) has been reported by several investigators for seminiferous tubules (Tuck ef al., 1970 ; Levine and Marsh, 1971 ; Gladwell, 1977). Recent measurements by one of us (R. T. G.) have shown that the potential inside the rete is similar. Consequently potassium is moving against its electrochemical gradient from plasma into both testicular fluids, whereas sodium is moving down its electrochemical gradient. It is therefore possible for a high potassium fluid to be secreted in the fubules, and for the concentration of potassium in this fluid to be changed to a new value when it reaches the rete, or as it passes through the fubuli recti. This change could result from a greater permeability of the rete epithelium to potassium. The concentration of potassium in the RTF, which is still about three times higher than plasma could depend on continued secretion of potassium by the rete epithelium or the maintenance of an effective diffusion barrier.

\section{Permeability of seminiferous fubules and rete testis to potassium and sodium.}

An estimate can be made of the relative permeabilities of the two epithelia to the two ions, but such estimates will be affected by such factors as the ratio of epithelial area to fluid volume. However, with this proviso in mind, it can be said that radioactive potassium appears more rapidly in STF than in RTF, but when $K_{\text {out }}$ (which allows for the differences in equilibrium concentration) is calculated, it would appear that the rete is more permeable to potassium than to sodium, and that the permeability of the tubules to both ions is less than that of the rete to potassium and comparable to the permeability of the rete to sodium (fig. 3). These differences in permeability could explain the changes in ionic composition.

The permeability to radioactive testosterone is high in both rete and tubules (Cooper and Waites, 1975 ; Setchell and Main, 1975). However the tubules are bathed in a testosterone-rich interstitial fluid whereas the blood supplying the rete is only marginally higher than peripheral arterial blood, due to exchange of testosterone from vein to artery in the spermatic cord (Free and Tillson, 1975). Therefore, there would be a tendency for testosterone to diffuse into the tubules, and out of the rete.

The differences in protein concentration are more difficult to explain, unless one postulates selective resorption of protein in the rete or tubuli recti. The latter possibility is supported by our observation that Sudan black particles formed in the tubules by injecting an alcoholic solution of the dye, are selectively removed by one tubulus 
rectus. This has important implications in considering possible routes of passage of inhibin out of the testis (Setchell, Main and Davies, 1977).

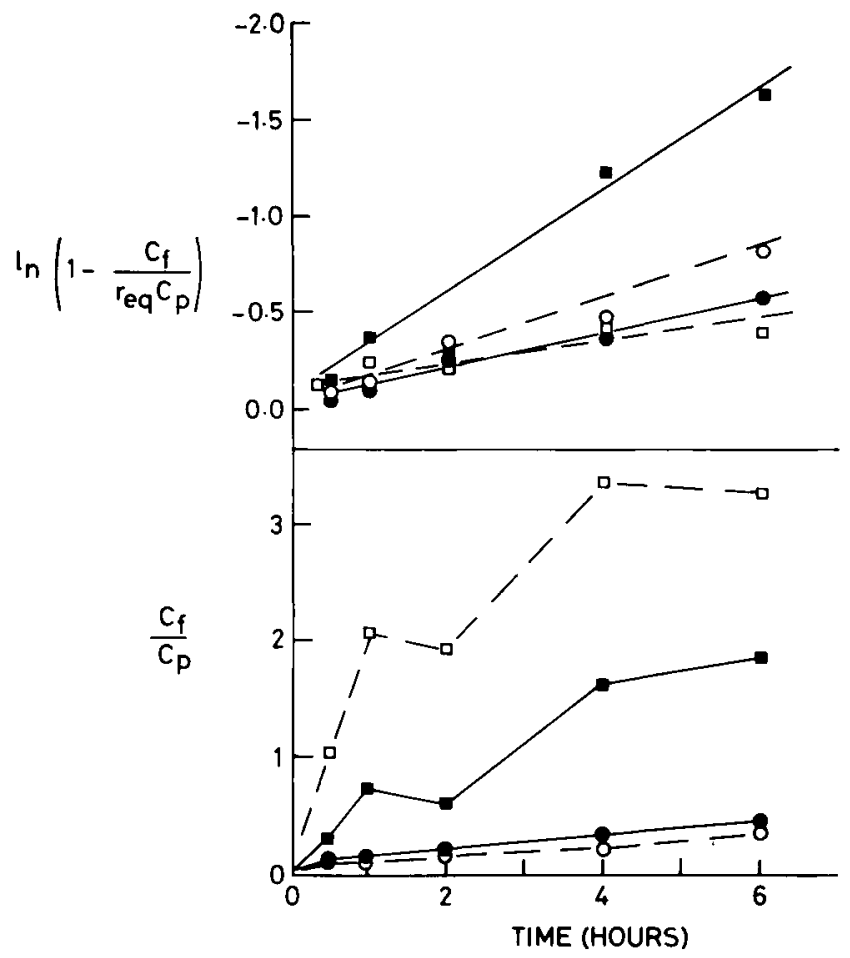

FIG. 3. - Lower panel : The seminiferous fubule (STF, $\square, 0)$ and rete festis $(R T F, \bullet, \bullet)$ fluid to plasma ratios $\left(C_{\mathrm{p}} / \mathrm{C}_{\mathrm{p}}\right)$ for radioactive potassium $\left(\mathrm{K}^{42}, \square, \square\right)$ and sodium $\left(\mathrm{Na}^{24}, \mathrm{o}, \bullet\right)$ at various times after and intraperitoneal injection of the isotope. The concentration in STF was estimated by the " difference " fechnique and that in RTF measured directly in samples collected $21 \mathrm{hr}$ after efferent duct ligation.

Upper panel : The same data replotted as the function $\ln \left(I-C_{f} / r_{e q} . C_{p}\right)$ against time; this function takes into account the ratio $\left(r_{\mathrm{eq}}\right)$ of the equilibrium concentrations of potassium and sodium in the two fluids, compared with plasma. The slope of this line gives the transfer constant ( $K_{\text {out }}$ in $\min ^{-1}$, Davson, 1967) which is an estimate of the permeability of the epithelium.

\section{Calculation of flow rate of fluid in the seminiferous tubules.}

From the rate of weight gain by the testis after efferent duct ligation (Setchell, 1970 ) and from the rate of flow of fluid from a rete testis catheter, after accumulated fluid has been removed (Tuck ef al., 1970) it can be calculated that fluid normally leaves the rat testis at a rate of about $20 \mu \mathrm{l} / \mathrm{hr}$. If we accept the two-fluid theory in its simpler form, i.e. excluding primary fluid, then 22 p. 100 of RTF comes from the tubules, if the concentrations of sodium in RTF and STF are used as the basis for calculation, and 33 p. 100 if potassium values are taken. Total fluid movement along all the tubules would then be 4.4 or $6.6 \mu \mathrm{l} / \mathrm{hr}$, and if there are about 30 tubules, as Clermont and Huckins (1961) state, each tubule would have a flow of 0.15 or $0.22 \mu \mathrm{l} / \mathrm{hr}$ if they all contribute to the same extent. If all the fluid leaving the rete originated in the tubules, then each would contribute about $0.7 \mu \mathrm{l} / \mathrm{hr}$. 
Fluid flow has been estimated in 2 ways. First by sampling as much fluid as possible from one tubule over a period of about $1 \mathrm{hr}$; about $1 \mu \mathrm{l} / \mathrm{hr}$ could consistently be obtained. Second, by infusing aqueous solutions of Lissamine green into one fubule at varying rates, and assessing visually the degree of dilution of the infused dye. This technique is obviously subject to considerable error, but it is clear that flow rates of $0.5 \mu \mathrm{l} / \mathrm{hr}$ tubule or more are usual.

\section{Characteristics of fluid movement.}

The nature of fluid movement in the tubule can be deduced from the behaviour of a small droplet of coloured oil in the lumen. Movement can be in either direction, sometimes slow and continuous, occasionally very rapid and irregular while in some tubules a rapid movement in one direction was followed by a slow progression back in the opposite direction. Similar variations in direction and velocity of movement have been observed during the infusion of aqueous solutions of dye.

Most sections of tubule do seem to have a " preferred 》 direction of movement. Unfortunately it is not yet possible to say whether or not this is toward the nearer tubulus rectus. It must also be remembered that all these observations and indeed all samplings have been done on superficial parts of tubules.

\section{"Progression » of focal lesions in the seminiferous tubules.}

Suoranta (1971) noticed that a focal lesion in a seminiferous tubule produced by a hot needle " progressed 》 along the fubule usually towards the rete. We have oblained similar results with lesions produced by intratubular injections of formaldehyde or cadmium chloride, and also after blocking the lumen of one tubule with a plug of latex.

It is probably relevant that in some rats, which had been Busulphan-treated or $X$-irradiated in utero, a certain number of entire fubules are apparently normal histologically and others are completely free of germ cells. The fluid in the germ cell-free tubules is like serum in its ionic composition; the fluid in the tubules containing spermatozoa contains much higher concentrations of potassium, approaching those in the tubules in normal testes. (Levine and Marsh, 1975, for Busulphan-treated rats ; Hinton and Setchell, unpublished observations, for X-irradiated rats). These observations suggest that fluid can be secreted by the Sertoli cells in the absence of germ-cells, but that the germ-cells induce a change in the composition of the secretion produced.

\section{Conclusions.}

A somewhat clearer picture is now emerging of fluid movements inside the seminiferous tubules and rete of the rat testis. Each tubule produces about $0.7 \mu \mathrm{l} / \mathrm{hr}$ of a hypertonic fluid rich in potassium, testosterone and inositol. The fluid flows along the tubule in either direction, and the rate of flow fluctuates widely from time to time. The potassium concentration is reduced to a lower value when the fluid reaches the rete, probably because of the greater permeability of the rete to potassium. As the fluid reaches the rete, the concentrations of testosterone and protein are also reduced ; 
there is no change in the concentration of inositol or spermatozoa. The unique composition of the fluid in the tubules is maintained by the blood-testis barrier and the fluid is probably secreted by the somatic Sertoli cells inside the barrier. The germ cells appear to be able to influence the secretion by the somatic cells under some conditions. The composition of STF is altered when there is complete absence of germ cells, for example in rats which had been X-irradiated or treated with Busulphan in utero, but the composition of RTF (Setchell and Waites, 1972) and STF (Hinton and Setchell, unpublished observation) is not affected by a temporary depletion of the germinal epithelium following local heating of the testis.

The fluid in the tubular lumen is important because it is the milieu in which the later stage of spermatogenesis occur. In addition to its obvious role in moving the released spermatozoa out of the testis, fluid movement along the tubules seems to be necessary for normal spermatogenesis. This may involve merely the removal of waste products or a more positive effect such as the transport of some essential metabolite to cells further along the tubule. The fluid in the lumina of the tubules could also be responsible for the transmission of a messenger which initiates a new cycle of the seminiferous epithelium in the adjacent section of tubule, and thus produces the orderly progression of the stages of the seminiferous epithelium, in decreasing numerical order from both ends of the tubule to the " site of reversal » (Perey, Clermont and Leblond, 1961 ; Hochereau, 1963). The possible existence of such a messenger is supported by the findings of Byskov and Saxen (1976) and $O$ and Baker (1976) that a stimulator of meiosis in cultured fetal testes and ovaries is produced by the fetal rete ovarii and an inhibitor of ovarian meiosis is produced by the fetal testis.

$27^{\text {e }}$ Congrès infernational des Sciences physiologiques, Symposium "Germ and somatic cell interaction " Paris, 21-23 juillef 1977.

Résumé. La composition des fluides du testicule ef du rete testis du rat montre des différences dans la concentration des ions des stéroïdes et des protéines suggérant que deux types de liquides sont sécrétés. Mais en tenant compte du nombre de spermatozoïdes et de la concentration en inositol, il apparaît maintenant plus vraisemblable que la sécrétion provient des tubes séminifères, mais que sa composition est modifiée quand il traverse les tubes droits ou quand il atteint le rete testis. La perméabilité du rete est sensiblement plus haute pour le potassium que pour le sodium. Elle est comparable pour le sodium à la perméabilité des tubules à ces deux ions.

La différence de potentiel arec le sang est la même pour les deux régions (environ $5 \mathrm{mV}$ dans la lumière).

Les mouvements de liquide le long des tubules ont été observés en utilisant de petites gouttes d'huile. Le liquide se déplace de chaque côté et à des vitesses très différentes de temps en temps. Le taux observé du flux liquide supporte la suggestion que la majorité du liquide est formé dans les tubules.

Des lésions focalisées dans un tube séminifère progressent le long du tubule ef l'obstruction de la lumière entraîne aussi une dégénérescence progressive.

A partir d'études de rat dont le nombre de cellules germinales a été réduit, il ressort que la sécrétion par les cellules de Sertoli peut continuer en l'absence de cellules germinales mais que la composition de la sécrétion peut en être affectée.

Ainsi le liquide des tubules est peut-être un véhicule important dans les interactions entre cellules germinales et cellules somatiques à l'intérieur des tubules. 


\section{References}

BEAUMONT H. M., 1960. Changes in the radiosensitivity of the testis during fotal development. Int. J. Radiat. Biol., 2, 247-256.

BYSKOV A. G., SAXEN L., 1976. Induction of meiosis in fetal mouse testis in vitro. Develop. Biol., 52, 193-200.

CLERMONT Y., HUCKINS C., 1961. Microscopic anatomy of the sex cords and seminiferous tubules in growing and adult male albino rats. Am. J. Anat., 108, 79-97.

COMHAIRE F. H., VERMEULEN A., 1976. Testosterone concentration in the fluids of seminiferous tubules, the interstitium and the rete testis of the rat. J. Endocr., 70, 229-235.

COOPER T. G., WAITES G. M. H., 1975. Steroid entry into rete testis fluid and the blood-testis barrier. J. Endocr., 65, 195-205.

DAVSON H., 1967. Physiology of the cerebrospinal fluid. Churchill, London.

DYM M., 1974. The fine structure of monkey Sertoli cells in the transitional zone at the junction of the seminiferous tubules with the fubuli recti. Am. J. Anat., 140, 1-26.

FREE M. J., TILLSON S. A., 1975. Local increase in concentration of steroids by venous-arterial transfer in the pampiniform plexus. Curr. Top. molec. Endocr., 2, 181-194.

GLADWELL R. T., 1977. The effect of temperature on the potential difference and input resistance of rat seminiferous tubules. J. Physiol., 268, 111-121.

HARTREE E. F., 1972. Determination of protein : a modification of the Lowry method that gives a linear photometric response. Anal. Biochem., 48, 422-427.

HENNING R. D., YOUNG J. A., 1971. Electrolyte transport in seminiferous tubules of the rat studied by the stopped flow microperfusion technique. Experientia, 27, 1037-1039.

HINTON B. T., SETCHELL B. P., WHITE R. W., 1977. The determination of myo-inositol in micropuncture samples from the testis and epididymis of the rat. J. Physiol., 265, 14P-15P.

HOCHEREAU M.-T., 1963. Etude comparée de la vague spermatogénétique chez le taureau et chez le rat. Ann. Biol onim. Biochim. Biophys., 3, 5-20.

HOWARDS S. S., JOHNSON A., JESSEE S., 1975. Micropuncture and microanalytic studies of the rat testis and epididymis. Fertil. Steril., 26, 13-19.

JOHNSON A., HOWARDS S. S., 1977. Hyperosmolarity in intraluminal fluids from hamster testis and epididymis : a micropuncture study. Science, 195, 493-495.

KORMANO M., KOSKIMIES A. I., HUNTER R. L., 1971. The presence of specific proteins in the absence of many serum proteins in the rat seminiferous fubule fluid. Experientia, 27, 14611463.

LEVINE N., MARSH D. J., 1971. Micropuncture studies of the electrochemical aspects of fluid and electrolyte transport in individual seminiferous tubules, the epididymis and the vas deferens in rafs. J. Physiol., 213, 55-570.

LEVINE N., MARSH D. J., 1975. Micropuncture study of the fluid composition of "Sertoli cell-only » seminiferous tubules in rats. J. Reprod. Fertil., 43, 547-550.

O W.-S., BAKER T. G., 1976. Initiation and control of meiosis in hamster gonads in vitro. J. Reprod. Fertil., 48, 399-401.

PEREY B., CLERMONT Y., LEBLOND C. P., 1961. The wave of the seminiferous epithelium in the rat. Am. J. Anat., 108, 47-77.

SETCHELL B. P., 1970. The secretion of fluid by the testes of rats, rams and goats, with some observations on the effects of age, cryptorchidism and hypophysectomy. J. Reprod. Fertil., 23, 79. 85.

SETCHELL B. P., MAIN S. J., 1975. The blood-testis barrier and steroids. Curr. Top. molec. Endocr., 2, 223-233.

SETCHELL B. P., WAITES G. M. H., 1972. The effect of local heating of the testis on the flow and composition of rete testis fluid in the rat, with some observations on the effects of age and unilateral castration. J. Reprod. Fertil., 30, 225-233.

SETCHELL B. P., WAITES G. M. T., 1975. The blood-testis barrier. In Handbook of Physiology, Section Endocrinology, 5, 143-172. 
SETCHELL B. P., HINTON B. T., JACKS F., DAVIES R. V., 1976. The restricted penetration of iodinated rat FSH and LH into the seminiferous tubules of the rat testis. Molec. cell. Endocr., 6, 59-69.

SETCHELL B. P., MAIN S. J., DAVIES R. V. 1977. Inhibin. In JOHNSON A. D., GOMES W. R., The festis, Vol. 4, 184-238 Acad. Press, New-York.

SUORANTA H., 1971. Tubular damage caused by local thermal injury or microembolization of the rat testis. Virchows Arch. Abt. B., 8, 299-308.

TUCK R. R., 1969. An investigation of the fluid secreted by the seminiferous fubules and rete testis of the rat. B. Sc. (Med) Thesis, Univ. of Sydney.

TUCK R. R., SETCHELL B. P., WAITES G. M. H., YOUNG J. A., 1970. The composition of fluid collected by micropuncture and catheterization from the seminiferous tubules and rete testis of rats. Pfliigers Arch., 318, 225-243.

WAITES G. M. H., 1977. Fluid secretion. In JOHNSON A. D., GOMES W. R., The festis, Vol. 4, 91-123 Acad. Press, New-York. 